\title{
Green zoning regulation under price discrimination $^{* 1}$
}

\author{
Hamid Hamoudi ${ }^{2}$, María J. Moral ${ }^{3}$
}

\begin{abstract}
This study aims to examine urban zoning within a linear city in a Bertrand duopolistic competition framework with price discrimination and linear transportation costs. It analyses the effects of introducing an environmental area where economic and residential activity are not allowed. The welfare function used to determine the optimal size of the green area allows for a possible regulator's bias in favour of firms/consumers. It is shown that location-price competition can be either reduced or increased depending on the size of the green area. The results indicate when a regulator implements green zoning, under linear transportation costs, influences the optimal location of firms (because these locations depend on the size of the green zone). In consequence, zoning may be used as an effective industrial or urban policy tool.
\end{abstract}

Key words: spatial discrimination, duopoly, zoning, environmental effects

JEL classification: D43, L13, R38, Q58

\section{Introduction}

Urban zoning refers to the practice of dividing the city into reserved sections for specific uses such as, environmental, residential, commercial or industrial.

* Received: 18-10-2016; accepted: 31-05-2017

1 The second author acknowledges research funding from the Spanish Ministry of Science and Innovation, Grant no. ECO2014-52051R and ECO2015-69334.

2 Associate Professor, Department of Foundations of Economic Analysis, Faculty of Legal and Social Sciences, University of King Juan Carlos (URJC), Paseo de los Artilleros s/n, 28032. Madrid, Spain. Scientific affiliation: microeconomics and industrial organization. Phone: +3491 488 7853. E-mail: hamid.hamoudi@urjc.es. Personal website: https://gestion2.urjc.es/curriculum/ pdicv?id= hamid.hamoudi.

3 Associate Professor, Department of Applied Economics, National Distance Education University (UNED), Paseo Senda del Rey s/n, 28040, Madrid, Spain. Scientific affiliation: microeconomics and industrialorganization.Phone:+3491398 8930.E-mail:mjmoral@cee.uned.es.Personal website: http://mjmoral.webs.uvigo.es/(corresponding author). 
This article examines a spatial discrimination framework to analyse alternatives to establish an environmental area inside the city where economic activity and residential use are not permitted. This model introduces the effects of zoning on both firms' competition and consumers' utility level is considered.

Today about $55 \%$ of the world's population lives in cities; but in 2050 around twothirds will reside in urban areas. Then the urban planning is a crucial issue for public administrations. There are, of course, many areas on which to focus attention on the planning strategy of cities of tomorrow. One of them is related with the idea that economic competitiveness must be based on the environmental sustainability of the cities (European Commission, 2011).

In this sense, we are interested in analysing the effects of implementing a green zone in the city as much on the benefits of the companies as on the well-being of the citizens. On the one hand, when considering sites for new business premises firms are influenced by incentives and restraints from policy makers to establish their activities. At the same time city-planners often face a trade-off when trying to serve divergent interests from different economic agents. Zoning, thus, becomes a useful instrument to plan rational occupation of spaces by redirecting businesses away from locations where their presence is deemed incompatible with certain policy objectives. On the other hand, large cities around the world face this type of zoning decisions when introducing new green areas, because it offers benefits for residents mainly related to health effects (World Health Organization, 2016), but also with other related with the enhancing sustainable urbanization (European Commission, 2015).

All of this shows the importance of providing an analysis on one of the fundamental aspects of this urban policy, such as the size of the green zone and its economic, environmental and congestion effects. Our research is interesting because it allows one to compute the optimal size of a green zoning in a realistic scenario.

This study introduces a green zoning in a Hotelling's linear city in a spatial competition context à la Bertrand. The main starting assumptions of the model with price discrimination (such as linear transport costs) were formalized in Hurter and Lederer (1985) and Lederer and Hurter (1986). We expand this model by introducing elements related to zoning regulation and its impact on the environment. We introduce a regulatory authority whose welfare function is equal to a linear combination of the firms' profits and the consumers' total surplus and we allow it to change depending on whether the regulator wants to benefit more from firms or consumers. We consider a utility function that incorporates the effects of the green zone in a more complex albeit realistic way. In the utility function a positive externality is included in order to pick the effect of improvements in the environment. Moreover, a negative externality arises because it diminishes the space for residential area increasing the congestion. 
Our aim is to determine the optimal zoning decision of the social planner under these conditions that modify behaviour of companies and consumers. The model is a first step towards capturing the relationship between transportation costs, the degree of consumer satisfaction, and the bias from the regulator because all of these hypotheses determine the optimal dimension of the green area.

In sum, the hypothesis that we want to validate is whether a green zoning regulation changes the equilibrium. If so, then we calculate the impacts on the optimal locations and the equilibrium prices of the firms.

The remainder of the paper is organized as follows. Section 2 presents the literature review. Section 3 describes methodology to model and compute the equilibrium in location. Section 4 presents the analysis, the results and discusses two cases. On the one hand, the case of pure market effects and the general case in which the regulator takes into account both effects (i.e. market effects vs. green zone). Finally, section 5 presents the conclusions and explores some policy implications.

\section{Literature review}

The literature on spatial discrimination à la Hotelling considers two main types of competition: Cournot (quantity) and Bertrand (price) competition. The analysis via quantities ${ }^{4}$ in the linear city goes back to Hamilton et al. (1989). Many other studies have followed this approach (Anderson and Neven, 1991; Gupta et al., 1997; Chamorro-Rivas, 2000; Benassi et al., 2007). The analysis via prices or price discrimination was first developed by Hoover (1937) and Lerner and Singer (1937). Other authors have extended their results to a more formal framework such as Hurter and Lederer (1985) and Lederer and Hurter (1986). ${ }^{5}$

The literature on zoning within a spatial competition framework also includes the analysis in terms of quantity and price competition. One of the first models on Bertrand competition is found in Lai and Tsai (2004), in the same vein more recent works are Hamoudi and Risueño (2012), and Bárcena and Casado (2014). For the case of Cournot competition models other authors such as Matsumura and Shimizu (2005), Chen and Lai (2008) or Colombo $(2011,2012)$ have explored the implications of introducing zoning.

The main focus of the spatial competition literature above mentioned is to determine the optimal choice of firm location. Depending on the assumptions and functional specifications from the models, different location patterns arise: dispersion,

\footnotetext{
4 The first spatial competition studies à la Cournot was developed by Greenhut and Ohta (1975).

5 An excellent explanation of this type of models can be found in Anderson et al. (1992, chapter 8).
} 
agglomeration and/or intermediate paths. ${ }^{6}$ This study extends this approach one step further by analysing the key factors influencing the size of a regulated green area. In order to do so a three-stage game is solved through backward induction in which consumers, firms and the regulator interact to determine the optimal size of the area for different parameter values.

Our study resembles Bárcena and Casado (2014) setup in the sense that these authors consider a regulator in the price discrimination model proposed by Hunter and Lederer. These authors introduce a regulator that does not decide the zoning dimension and fixes the possible locations for firms; in consequence, they only solve a two-stage game. However, we contemplate a more general model in several issues. Firstly, we introduce a regulator which chooses the optimal dimension of the green area. Therefore, our model is formalised as a three-stage game and it is solved as a three-stage game using backward induction. Secondly, we specify and evaluate the environmental and congestion effects of the green zoning regulation, that is, we take into account positive and negative externality effects in the consumer's utility function.

\section{Methodology}

\subsection{The model}

A price-discrimination version of Hotelling's linear city model is examined under a regulatory authority in charge of the design of a green area. Consumers and firms are not allowed to locate in the green area denoted by: $\left[v_{1}, v_{2}\right]$. This area is assumed to be located between both firms so that: $0 \leq x_{1} \leq v_{1} \leq v_{2} \leq x_{2} \leq 1$, where, $x_{1}, x_{2}$ denote respectively the location of firm 1 and 2 . The location space for consumers and firms is, therefore, defined as: $\mathrm{I}=\left[0, v_{1}\right] \cup\left[v_{2}, 1\right]$. Notice that the displacement through the green zone is authorized. We denoted by " $v$ " the length of a green area: $v=v_{2}-v_{1}$; then $v \in[0,1]$.

In general, the urban plans try to combine green spaces with a growing population density. Then the regulator should maintain the proportionality between the buildable volume and the free spaces that serve to make human life more adequate. Consequently, the extreme case that the whole city is a green area does not seem very realistic, that is, the case $v=1$ is far from reality. Therefore, hereafter we limit this case considering a maximum value equal to $\hat{v}$ such that: $v \leq \hat{v}<1$.

Both firms produce a homogeneous good at a constant marginal cost " $\mathrm{c}$ " and choose a mill price. The delivered price, $p_{i}\left(x, x_{i}\right), i=1,2$, depends on the location of the consumer $x$ and the firm $x_{i}$, However, for the sake of simplicity it will be denoted

$\overline{6}$ For a general idea on the results within different spatial competition setups see Biscaia and Mota (2013). 
as: $p_{i}(x), i=1,2$. Following Hotelling (1929) a linear function is used to describe transport cost. The profit of firms is denoted by $\pi_{i}(v), i=1,2$.

There are $N$ consumers uniformly distributed along $I$, each buys one unit of the product and their reserve price $(S)$ is high enough to purchase the good. Surplus obtained when buying from the firm $i$ will be: $e_{i}(x)=S-p_{i}(x), i=1,2$. The consumers' total surplus $E_{T}($.$) will be obtained by aggregating for the whole population, N$.

The novelty of the model is the introduction of externalities associated with the green zone. Specifically, we consider two externalities due to environmental and congestion effects.

- Environmental effect:

This effect is due to people valuing positively the environmental consequences derived from a green area in their city: pollution reduction, space for leisure, etc. In particular, a moderated interest on the environment is assumed, that is, we specify a decreasing marginal rate for that positive externality. The following concave $^{7}$ function specifies this idea: $h(v)=\left(-v^{2}+\alpha v\right), \alpha \geq 0$. Where the parameter $\alpha$ describes the degree of satisfaction the individual obtains from green zones.

\section{- Congestion effect:}

This effect is a consequence of population density in the urban space. The expression is given by: $g(v)=\beta(1-v) / N, \beta \in R^{+}$. The parameter $\beta$ shows the satisfaction level for a consumer provided by an exclusively residential zone $\beta=N g(0)$. The function $g(v)$ is decreasing in $v^{8}$, that is, more green space means less residential space leading to higher congestion.

Finally, both effects must be aggregated to quantify the total impact from a green area on consumer's welfare in a function that is denoted as "quality of life": $i_{m}(v)$. It shows the trade-off between environmental advantages and a higher congestion (population density) and is defined by:

$$
i_{m}(v)=\underbrace{\left[-v^{2}+\alpha v\right]}_{\begin{array}{c}
\text { environmental } \\
\text { effect }
\end{array}}+\underbrace{\left[\frac{\beta(1-\mathrm{v})}{N}\right]}_{\begin{array}{c}
\text { congestion } \\
\text { effect }
\end{array}}, \alpha, \beta \in R^{+}, v \in[0, \hat{v}]
$$

\footnotetext{
$\overline{7}$ Concavity in function $h(v)$ shows a moderated interest on the environment with a decreasing marginal rate. For the convex case, $h(v)=v^{2}+\alpha v$; as well as the linear case, $h(v)=\alpha v$, extreme solutions are found.

${ }^{8}$ Notice that $g(v) / \beta$ is the inverse function of population density in the space of length $(1-v)$.
} 
Where parameter $\alpha$ describes the degree of satisfaction obtained by an individual from green zones and $\beta$ stands for the satisfaction level enjoyed by a consumer from an exclusively residential zone. On the other hand, $v$ represents the length of a green area: $v=v_{2}-v_{1}$.

A new formulation is given by: $i_{m}(v)=-v^{2}+\gamma v+\beta / N, \quad \gamma \in R, \beta \in R^{+}, v \in[0, \hat{v}]$.

Let $\gamma=\alpha-(\beta / N)$ be the parameter describing spatial preferences. It represents the bias from consumers towards an exclusively residential space when $\gamma \leq 0$ or alternatively towards a space with a green area when $\gamma \geq 0$.

The total environmental $\operatorname{effect}^{9} I_{m}(v)$ will be obtained by aggregating for the whole population $(N)$ :

$$
I_{m}(v)=\sum_{m=1}^{N} i_{m}(v)
$$

Following the specification in Hamoudi and Risueño (2012), the regulator has a bias for firms or consumer, his objective function is defined as ${ }^{10}$ :

$$
W(v)=\lambda\left(\pi_{1}(v)+\pi_{2}(v)+(1-\lambda)\left(E_{T}(v)+I_{m}(v)\right)\right.
$$

In this function: $\lambda,(0 \leq \lambda \leq 1)$, stands for the weight given by the regulator to firms' profit, $\left(\pi_{1}(v)+\pi_{2}(v)\right)$, in accordance with his/her political bias. Inversely, $(1-\lambda)$, is the weight given to consumers' utility, $\left(E_{T}(v)+I_{m}(v)\right)$. This functional form for welfare shows that when $\lambda>1 / 2$, firm's profit is more important than consumer's disutility for global welfare and the opposite holds when $\lambda<1 / 2$.

The model is formalised as a three stage-game. In the first stage, the regulator chooses the optimal size of the green area. In the second stage, firms simultaneously choose their locations; and at the final stage, firms decide on their prices. Backward induction will be employed to solve the equilibrium. As usual in these models, arbitrage among consumers is not allowed.

Equilibrium in prices is solved through competition à la Bertrand. The solution is similar to Hurter and Lederer (1985), and Lederer and Hurter (1986), such as we can see in equation (4) and Figure 1:

9 Notice that the optimal size of green zone under exclusively environmental effects is associated to the extreme cases: 0 if $\gamma \leq 0$; 1 if $\gamma \geq 2$ and $\gamma / 2$ if $0 \leq \gamma \leq 2$.

${ }^{10}$ Notice that we do not include in the model the cost for zoning because we are interested in environmental effects. In any case, to take into account this issue would add a budget restriction for social problem of the regulator doing more complex the problem solution, but it won't change the main results. 


$$
p_{1}^{*}(x)=p_{2}{ }^{*}(x)=\operatorname{Max}\left\{c+t\left|x_{1}-x\right|, c+t\left|x_{2}-x\right|,\right.
$$

for every $x \in\left[0, v_{1}\right] \cup\left[v_{2}, 1\right]$

It should be highlighted that the optimization strategies of firms are not modified when a green zone is introduced. This type of equilibrium was first identified by Hoover (1937). With spatial price discrimination, the strategy set are much "broader" since each firm chooses a price function rather than a single mill price, that is, has more flexibility in its price choice. Given this equilibrium result, the market becomes segmented at $v_{1}, v_{2}$, firm 1 serves residential area $\left[0, v_{1}\right]$, and firm 2 sells in $\left[v_{2}, 1\right]$. Each company acts, consequently, each company acts as a de facto monopoly. Notice that when $x_{1}=x_{2}$, the equilibrium delivered price equals the common supplying cost and firms make zero profits.

Figure 1: Equilibrium delivered price schedule and profits under zoning regulation

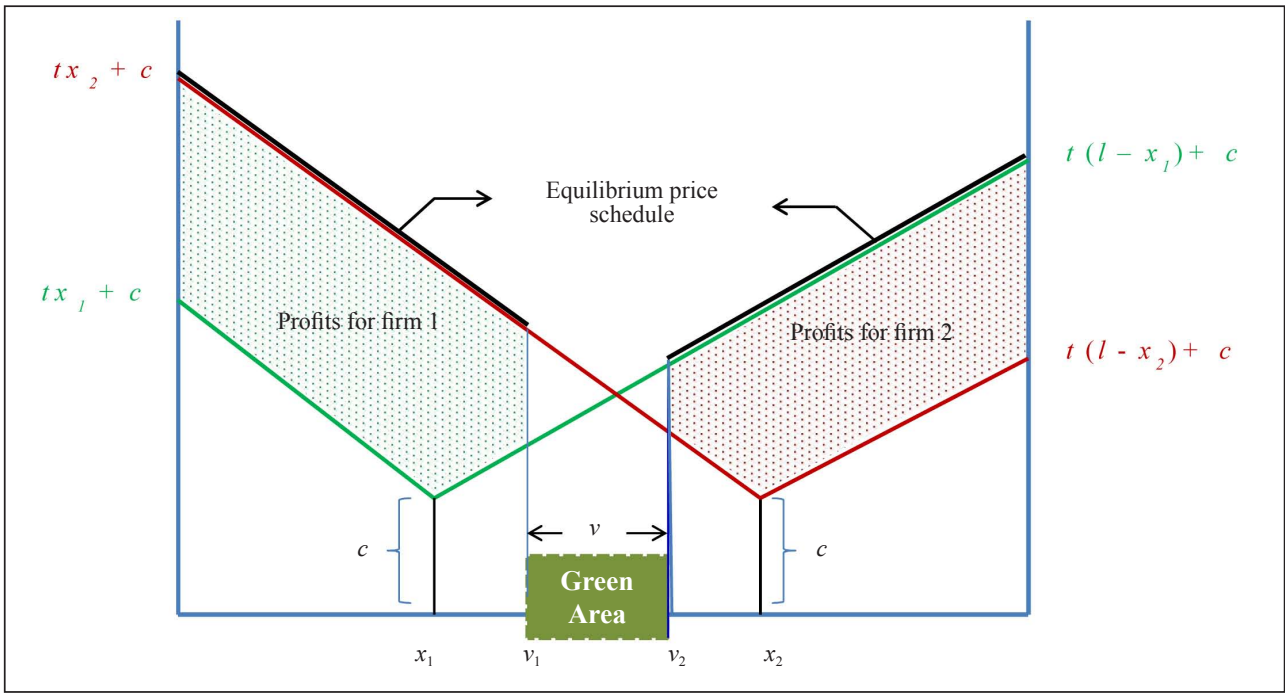

Source: Authors

\subsection{Optimal locations}

The result for equilibrium in prices is used in the second stage of the game to determine the optimal duopolistic location. Given the expression (4), the profit at each point is the equilibrium price minus the corresponding cost. Thus, the benefit functions of firms are formulated as:

$\pi_{1}\left(x_{1}, x_{2}, v_{1}, v_{2}\right)=\frac{t N}{1-v}\left\{x_{1}\left(x_{2}-x_{1}\right)+\frac{1}{4}\left(x_{2}-x_{1}\right)^{2}-\frac{1}{4}\left(x_{1}+x_{2}-2 v_{1}\right)^{2}\right\}$ 
$\pi_{2}\left(x_{1}, x_{2}, v_{1}, v_{2}\right)=\frac{t N}{1-v}\left\{\left(1-x_{2}\right)\left(x_{2}-x_{1}\right)+\frac{1}{4}\left(x_{2}-x_{1}\right)^{2}-\frac{1}{4}\left(2 v_{2}-x_{1}-x_{2}\right)^{2}\right\}$

Firm's profits are represented by the hatched area in figure 1 .

Firms maximize their profits simultaneously and equilibrium locations are derived:

$$
\begin{aligned}
& x_{1}^{*}\left(v_{1}\right)=\frac{v_{1}}{2} \\
& x_{2}^{*}\left(v_{2}\right)=\frac{1+v_{2}}{2}
\end{aligned}
$$

This optimality results is not fortuitous. Since each firm behaves like a monopoly, the outcome corresponds to a midpoint location within its market. An important consequence here is that the regulator may use the size of the green area as an industrial policy tool to reduce monopoly power of firms, thus, increasing market competition. The profits of firms in equilibrium location are given by the following expressions:

$$
\begin{aligned}
& \pi_{1}^{*}\left(v_{1}, v_{2}\right)=\left(t N v_{1} / 4\left(1-\left(v_{2}-v_{1}\right)\right)\right)\left\{-3 v_{1}+2 v_{2}+2\right\} \\
& \pi_{2}^{*}\left(v_{1}, v_{2}\right)=\left(t N / 4\left(1-\left(v_{2}-v_{1}\right)\right)\right)\left\{-3 v_{2}^{2}+2 v_{2} v_{1}+2 v_{2}-2 v_{1}+1\right\}
\end{aligned}
$$

Following Anderson et al. (1992: 328-329), we can prove that equilibrium locations are socially optimal. In fact, it can be shown that when no green area exists, $v_{2}-v_{1}$, firms locate in equilibrium so $x_{1}^{*}=1 / 4, x_{2}^{*}=3 / 4$. In this case, $v_{1}=v_{2}=1 / 2$ and profits remain the same (equal to $3 t N / 16$ ).

Given the above results, the planner will examine the optimal policies depending on the length of the green zone. However, the specification of social welfare (expression (3)) implicitly assumes that a regulator does not discriminate between both firms or amongst consumers. Thus, only the symmetrical case is considered henceforth: $v_{1}+v_{2}=\hat{v}$. Under this assumption, the expressions for the optimal locations (6.a) and (6.b) are $x_{1}^{*}(v)=0.25(1-v)$ and $x_{2}^{*}(v)=0.25(3+v)$ that leading to identical profits for both firms denoted by:

$$
\pi_{1}^{*}(v)=\pi_{2}^{*}(v)=\frac{t N}{16}\{5 v+3\}
$$

Notice that firm's profits are increasing with the size of the green area and the transportation cost per unit of distance ${ }^{11}, t$.

$\overline{{ }^{11} \forall v \in[0,1],\left(\partial \pi_{i}^{*} / \partial v\right)}>0, \forall t>0,\left(\partial \pi_{i}^{*} / \partial t\right)>0$ 
Therefore, if firms can choose the dimension of the environmental area they would prefer the largest possible size (that is, $v=\hat{v}$ ). In this case, firms will be located as far away as possible from each other, $\left(x_{1}^{*}(v)=0.25(1-\hat{v}), x_{2}^{*}(v)=0.25(3+\hat{v})\right)$. Competition is relaxed under this scenario and firms achieve "monopoly rents" which bring about maximum profits: $\pi_{1}^{*}(1)=\pi_{2}{ }^{*}(1)=\frac{N}{2} t$.

What happens to consumer's surplus when a good is purchased given that the optimal location and prices have been modified due to the existence of a regulated area? Since the market is segmented it is necessary to distinguish between customers:

The surplus from an arbitrary consumer located in the segment served by firm 1 equals:

$$
e_{1}^{*}(x)=S-p_{2}(x)=S-t\left[\left(\frac{3+v}{4}\right)-x\right]-c
$$

An arbitrary consumer located in $x \in\left[v_{1}^{*}, 1\right]$ buys from firm 2 obtaining a surplus given by:

$$
e_{2}^{*}(x)=S-p_{1}(x)=S-t\left[x-\left(\frac{1-v}{2}\right)\right]-c
$$

The total utility for consumers from buying the good is obtained through aggregation:

$$
E_{T}^{*}(v)=\frac{N}{(1-v)}\left\{\int_{0}^{\frac{1-v}{2}} e_{1}^{*}(x) d x+\int_{\frac{1+v}{2}}^{1} e_{2}^{*}(x) d x\right\}=N\left[S-c-t \frac{(1+v)}{2}\right]
$$

Consumers' total surplus decreases with the size of the green area and the transportation cost per unit of distance ${ }^{12}, t$. As a result, if consumers could choose the optimal size for the non-urbanized area, they will prefer $v=0$. Subsequently, locations would be $x_{1}^{*}=1 / 4, x_{2}^{*}=3 / 4$, which are socially optimal for the two firms. An insight may be gained by not taking the benefits from the green are into consideration. Consumers will then prefer an entirely residential space which provides them with maximum level of utility: $N(S-c-t / 2)$. Their utility, nevertheless, diminishes as the transportation cost per unit of distance $(t)$ increases given null environmental (positive) effects.

$\left.\overline{{ }^{12} \forall v \in[0,1],\left(\partial E_{T}^{*}\right.} / \partial v\right)<0, \forall t>0,\left(\partial E_{T}^{*} / \partial t\right)<0$ 


\section{Analysis, results and discussion}

A key aspect in the model is the introduction of a regulator in charge of implementing the design of a green zone with length $v$ within the linear city. In this section, the optimal dimension of $v$ will be determined under two different situations. In the first scenario, the planner considers market effects (i.e. interaction between firms and consumers) but not environmental effects from the green area within the population. In a second scenario, the planner considers market effects but includes the consequences from the green zone for city inhabitants.

\subsection{Optimal size of the green area under pure market effects}

In this situation, the regulator does not take into account any externalities generated by the green area, thus, only market interactions between consumers and firms are considered. The analysis of this case is particularly interesting since it shows how the regulator might change the way the market works when choosing the dimension of a non-residential area. The goal is to examine changes in the behaviour of firms in terms of location and price. The welfare function of the regulator $W_{1}(v)$ is expressed as a linear combination of firms' profits $\pi_{i}^{*}(v), i=1,2$ and the total surplus for the population from buying the good $E_{t}^{*}(v)$. This can be formalized as follows:

$$
W_{1}(v)=\lambda\left(\pi_{1}^{*}(v)+\pi_{2}^{*}(v)\right)+(1-\lambda) E_{t}^{*}(v)
$$

By substituting $\pi_{1}^{*}(v), \pi_{2}^{*}(v)$ and $E_{T}^{*}(v)$ with their respective expressions (8) and (10), the following welfare function is obtained:

$$
W_{1}(v)=N\left\{\left[\frac{t}{8}(9 \lambda-4)\right] v+(1-\lambda)\left[S-c-\frac{t}{2}\right]+\frac{3}{8} \lambda t\right\}
$$

The optimal strategy of the regulator is given by:

$$
\begin{gathered}
v^{O M}=\operatorname{Arg} \underset{v}{\operatorname{Max}} W(v), \\
\text { s.t. } 0 \leq v \leq \hat{v}
\end{gathered}
$$

\section{Proposition 1:}

For $0 \leq v \leq \hat{v}$, the optimal size $v^{O M}$ of the green zone is:

$$
v^{O M}= \begin{cases}0 & \text { if } 0 \leq \lambda \leq 0.44 \\ {[0, \hat{v}]} & \text { if } \lambda=0.44 \\ \hat{v} & \text { if } 0.44 \leq \lambda \leq 1\end{cases}
$$

Proof: (see appendix). 
The optimal size associated with pure market effects is given by $v^{O M}$ (see equation 13). The most important result arising here is that the optimal size is not dependent on transportation cost per unit of distance $(t)$, but only on the bias towards firms from the regulator $(\lambda)$. It can be concluded that zoning regulation under a constant demand can either increase or decrease competition depending on the value of $\lambda$.

We can identify three distinct cases, depending on the value of $\lambda$ :

Firstly, the case $0 \leq \lambda \leq 0.44$, corresponds to a situation where a greater weight is attached to consumer's welfare in terms of global welfare. The residentialcommercial area reaches a maximum extension, $v^{O M}=0$, therefore, city inhabitants will enjoy more welfare in terms of space. The welfare function is equal to $W_{1}(0)=N\{(1 / 8) t(7 \lambda-4)+(1-\lambda)[S-\mathrm{c}]\}$.

The solution is the same as under consumers' favourite option because the location of firms (given by $x_{1}^{*}=1 / 4, x_{2}^{*}=3 / 4$ ) are socially optimal. In other words, the outcome $v^{O M}=0$ corresponds to a situation in which a greater weight is attached to consumer's welfare in terms of global welfare given that $\lambda \in[0,0.44]$. Consequently, the firm competition is intense.

Secondly, when $\lambda=0.44$, an optimum will be reached for $\forall v \in[0,1]$, the social welfare function is constant and independent from the size of the environmental area $v$. The welfare function is equal to $W_{1}(v)=(N / 9)[-t+5(S-c)]$, thus, decreasing with respect to $t$. The regulator is neutral. What this is means is that the regulator is indifferent on the size of the green area and may, therefore, take arbitrary decisions. In any case, under this solution, the optimal locations are: $x_{1}^{*}\left(v^{O M}\right)=0.25\left(1-v^{O M}\right)$, and $x_{2}^{*}\left(v^{O M}\right)=0.25\left(3+v^{O M}\right)$.

Lastly, when $0.44 \leq \lambda \leq 1$, the optimal green area extends along the whole city $v^{O M}=\hat{v}$. Given this total range of values for the weight factor, the regulator overvalues consumers' preferences when $\lambda \in[0.44,1 / 2)$. However, if $\lambda \in[1 / 2,1)$, the planner attaches a higher weight to firms over consumers. In the particular case corresponding to $\lambda=1 / 2$ the social optimum minimizes the total transport costs. In consequence, consumers are located at the extremes of the city and competition among firms is weak. The solution is similar to firms' preferred option. In this case, the welfare function is equal to: $W_{1}(v)=N\{t(2 \lambda-1)+(1-\lambda)[S-c]\}$. Given that this expression is increasing with respect to $t$ for $\lambda \in(1 / 2,1]$, the optimal locations of firms will be $x_{1}^{*}=0$, and $x_{2}^{*}=0$, respectively.

\subsection{Optimal size of green area: a general study}

This is the most general case as the planner takes into consideration both: market effects and green zone externalities. The optimal dimension of $v$ will be determined using the equilibrium results obtained in the previous section and expression (3) from the regulator's welfare function that includes the total environmental effect, $I_{m}(v)$. 
Therefore, welfare might also be reformulated as: $W_{2}(v)=W_{1}(v)+(1-\lambda) I_{m}(v)$. Substituting $W_{1}(v)$, and $I_{m}(v)$ with their respective expressions (12) and (2) the following expression is obtained:

$$
\begin{aligned}
W_{2}(v)= & N\left\{-(1-\lambda) v^{2}+\left[(1-\lambda) \gamma+\frac{t}{8}(9 \lambda-4)\right] v+\right. \\
& \left.+(1-\lambda)\left[\frac{\beta}{N}-\frac{t}{2}+S-c\right]+\frac{3}{8} \lambda t\right\}
\end{aligned}
$$

The optimal value of $v$ is obtained from the solution to the next problem:

$$
(P):\left\{\begin{array}{l}
\operatorname{Max} W_{2}(v) \\
v \\
\text { s.t. } 0 \leq v \leq \hat{v}
\end{array}\right.
$$

For $\lambda=1$, that is, the regulator does not take into account consumers' preferences, the welfare function from the regulator $W_{2}(v)$ will equal the added benefit of the duopolistic firms $\pi^{*}(v)$. Therefore, this entails a similar case to both firms choosing the size of the green area. Thus, the optimal dimension of the green area is $v^{O G}=\hat{v}$.

For $\lambda \neq 1$, with $0 \leq \lambda<1$, the welfare function (equation 14) can be rewritten as:

$$
W_{2}(v)=N(1-\lambda)\left\{-v^{2}+[\gamma-t f(\lambda)] v+\mathrm{K}\right\}
$$

Where:

$$
f(\lambda)=\frac{1}{8} \frac{9 \lambda-4}{1-\lambda}
$$

with $f(\lambda) \leq 0$, if $\lambda \in[0,0.4], f(\lambda) \geq 0$, if $\lambda \in[0.44,1)$, and

$$
K=\left[\frac{(7 \lambda-4)}{8(1-\lambda)} t+\left(\frac{\beta}{N}+S-c\right)\right]
$$

This expression (16) for the welfare function easily allows the determination of the optimal size of the green area as shown below:

Proposition 2:

For any $t \in \mathrm{R}^{+} \lambda \in[0,1]$, the optimal size of the green area, $v^{O G}=\operatorname{Arg} \underset{0 \leq v \leq \hat{v}}{\operatorname{Max}} W_{2}(v)$ is given by: 


$$
v^{O G}(t, \gamma, \lambda)=\left\{\begin{array}{llc}
0 & \text { if } & \gamma \leq-t f(\lambda) \\
v^{*} & \text { if } & -t f(\lambda) \leq \gamma \leq 2-t f(\lambda) \\
\hat{v} & \text { if } & 2-t f(\lambda) \leq \gamma
\end{array}\right.
$$

where $v^{*}(t, \gamma, \lambda)=(1 / 2)(\gamma+t f(\lambda)$ with $f(\lambda)$ as defined in expression (16.1).

Proof: (see appendix).

The optimal size $v^{O G}$, defined in expression (17), depends on the interrelation between the environmental preference of consumers $(\gamma)$, the transportation cost per unit of distance $(t)$, and the weight $(\lambda)$ attached to firms by the regulator.

As the value $\gamma$ increases the optimal size of the green area becomes bigger until it takes all available space. Thus, depending on the values of the above parameters, three solutions are obtained. However, both the value and the growth rate of the size, $v^{O G}$, depend on the sign of $f(\lambda)$ define in equation (16.1) and consequently on the different values the bias $(\lambda)$ takes.

When $\lambda \in[0,0.44], f(\lambda) \leq 0$, the regulator has a clear bias towards the interests of consumers in which case it is moderately inclined to set a green zone and will only promote it when a certain positive threshold is reached for the environmental preferences of consumers $\gamma,(0 \leq-t f(\lambda) \leq \gamma)$. Furthermore, as long as transportation cost per unit of distance is increased, the space allocated for the green area will go up.

Notice that when $\lambda=0.44, f(\lambda)=0$, the optimal size is independent from transportation cost per unit of distance, $t$, and the regulator's decision becomes similar to the case when market effects are not taken into consideration.

When $\lambda \in[0.44,1), f(\lambda) \geq 0$, a bias towards firms is observed, and the trend in favour of a green area sharpens as the value of the bias $\lambda^{13}$ increases. In this sense, the regulator implements a green area once a low value for the spatial preferences, $\gamma,(\gamma=-t f(\lambda) \leq 0)$ is reached, even though consumers have a preference for more residential space.

The environmental preference of consumers has an upper and a lower bound, $-t f(\lambda) \leq \gamma \leq 2-t f(\lambda)$ whereas the optimal size of the green area $v^{*}=(1 / 2)(\gamma+t f(\lambda))$, is noticeably higher when $\lambda \in[0.44,1)$, than when $\lambda \in[0,0.44]$.

In the recent literature, the articles closest to the research presented here are Hamoudi and Risueño (2012), and Bárcena and Casado (2014). We then set out our contributions in comparison to those articles.

\footnotetext{
$\overline{{ }^{13} \text { For } \lambda \in[0.44,1), f}(\lambda)$ it increases very rapidly.
} 
In the paper by Hamoudi and Risueño (2012), the authors make use of zoning in a circular market under spatial discrimination without the adoption of discrimination in prices, and without the consideration of environmental or urban issues. In consequence, they obtain two extreme results (a "weak competition" versus a "strong competition") according to the regulatory bias between consumers and firms.

From the regulation structure presented in Hamoudi and Risueño (2012), the paper by Bárcena and Casado (2014) analyses zoning in a linear market under spatial competition with discrimination in prices. The key difference of our contribution in comparison to this article is, however, to analyse the tradeoff of the effects for environmental improvements and for a greater congestion on both the location and the equilibrium prices of firms.

In sum, our contribution to spatial literature lies in the analysis of the zoning taking into account the effects of environmental and urban topics under a spatial discrimination model with Bertrand competition. This change in model specification significantly affects results. In particular, we obtain a broader result in terms of prices and locations: a "weak competition" $(v *=0)$, a "strong competition" $\left(v^{*}=\hat{v}\right)$, and an intermediate competition $v^{*}(\lambda) \in[0, \hat{v}]$, which depends also on the regulator's bias.

In economic terms, this model teaches us when planning the design of cities how to impose restrictions on the locations of companies taking into account the environmental aspects. In addition, that environmental policy can increase competition between companies and positively affect the welfare of consumers.

\section{Conclusions}

This study introduces an environmental area in a Hotelling's linear city with the objective of analysing the social welfare. This zoning model considers the implications in terms of the firm's decision on location and the well-being of consumers.

On the one hand, constraining the location of firms to a specified area might be used as an industrial policy instrument by a regulator aiming to redistribute economic activity to certain areas. This type of intervention, therefore, influences the degree of competition in the market.

On the other hand, the existence of a green area affects welfare levels of citizens through their "quality of life". Given that the green zone may not be inhabited by consumers, two externalities arise. A positive externality because of environmental improvements and the possibility of enjoying the space for leisure. And a negative externality linked to the increase of population density (i.e. congestion effect) 
brings about a disutility for consumers. As a consequence, the net effect from the green area on citizens' welfare must be calculated by formalizing the magnitude and direction of both externalities.

One of the contributions of this paper is a comprehensive specification that relies on the relationship among three key factors: the bias of the regulator towards firms or consumers, the transportation cost and the environmental effects. Evidently, the outcome depends on all of them. In this framework, optimal policies are obtained according to a weighted welfare function. It is shown that location and price competition might be stronger or weaker depending on the size of the environmental area. Thus, the main policy implication of this paper (i.e. in line with regulation literature) is to underline the role of zoning regulation as an influential competition policy tool.

Firstly, only market effects without externalities from the green area are considered. Under this hypothesis, the main result is that zoning policy is independent from transportation costs and, in consequence, the solution only depends on the regulator bias. In particular, if the bias is towards consumers, the outcome favours them. In contrast, when the regulator is biased towards firms, the outcome favours them. Interestingly, we identify a value of the parameter in the welfare function $(\lambda=0.44)$ for which the regulator becomes neutral - undecided on the size of the green area. This can lead to arbitrary decisions.

Finally, a more general context is analysed in which the regulator takes into account the market effects and negative externalities associated to the green zone. We find that the optimal size of the green zone depends on the bias from the regulator, the transportation cost per unit of distance and the externalities due to congestion versus environmental quality. The most relevant aspect here is that the introduction of transportation costs imposes more restrictive conditions on a regulator when implementing a green area in the city. Moreover, this effect increases when there exists a bias to benefit consumers.

An interesting extension of these results for future research would be to attach some value to space (land) by including another parameter in the utility function of consumers and firms. This approach would introduce a highly realistic assumption in the design of green areas in large cities where social urban dynamics (i.e. gentrification) is already taken place. Moreover, growth and city-design in new spaces could also be analysed by using a similar setup to the one in this paper. In this case, the length of this space will, therefore, become a strategic variable for the regulator. 


\section{References}

Anderson, S., Neven, D. (1991) "Cournot competition yield spatial agglomeration", International Economic Review, Vol. 32, No. 4, pp. 793-808, doi: 10.2307/ 2527034.

Anderson, S., De Palma, A., Thisse, J-F. (1992) Discrete Choice Theory of Product Differentiation, Massachusetts, London, England: The MIT Press Cambridge.

Bárcena-Ruiz, J. C., Casado-Izaga, F. J. (2014) “Zoning under Spatial Price Discrimination", Economic Inquiry, Vol. 52, No. 2, pp. 659-665, doi: 10.1111/ecin.12071.

Benassi, C., Chirco, A., Scrimitore, M. (2007) "Spatial discrimination with quantity competition and, high transportation costs: A note", Economics Bulletin, Vol. 12, No. 1, pp. 1-7.

Biscaia, R., Mota, I. (2013) "Models of spatial competition: a critical review", Papers in Regional Science, Vol. 92, No. 4, pp. 851-871, doi: 10.1111/j.14355957.2012.00441.x.

Colombo, S. (2011) "On the rationale of spatial discrimination with quantity-setting firms", Research in Economics, Vol. 65, No. 3, pp. 254-258, doi: 10.1016/j.rie. 2010.11.002.

Colombo, S. (2012) "On Optimal Zoning in a Linear Town with Cournot Competitors", Letters in Spatial and Resource Sciences, Vol. 5, No. 2, pp. 113118, doi: 10.1007/s12076-011-0072-x.

Chamorro-Rivas, J. (2000) "Spatial dispersion in Cournot competition," Spanish Economic Review, Vol. 2, No. 2, pp. 145-152, doi: 10.1007/PL00011438.

Chen, C. S., Lai, F. C. (2008) "Location choice and optimal zoning under Cournot competition", Regional Science and Urban Economics, Vol. 38, No. 2, pp. 119 126, doi: 10.1016/j.regsciurbeco.2008.01.009.

European Commission (2011) Cities of tomorrow. Challenges, visions, ways forward, Directorate General for Regional Policy. Available in: http://ec.europa. eu/regional_policy/conferences/citiesoftomorrow/index_en.cfm.

European Commision (2015) Towards an EU Research and Innovation policy agenda for Nature-Based Solutions \& Re-Naturing Cities. Final Report of the Horizon 2020 Expert Group on "Nature-Based Solutions and Re-Naturing Cities". Luxembourg: Directorate-General for Research and Innovation. Available in: http://bookshop.europa.eu/en/towards-an-eu-research-and-innovation-policyagenda-for-nature-based-solutions-re-naturing-cities-pbKI0215162.

Gupta, B., Debashis, P., Sarkar, J. (1997) "Spatial Cournot competition and agglomeration in a model of location choice", Regional Science and Urban Economics, Vol. 27, No.3, pp. 261-282, doi: 10.1016/S0166-0462(97)00002-1.

Greenhut, M. L., Ohta, H. (1975) "An alternative model of spatial pricing under competition". In M.L. Greenhut and H. Ohta, Theory of Spatial Pricing and Market Areas, Durham, N.C.; Duke University Press. 
Hamilton, J., Thisse, J.-F., Weskamp, A. (1989) "Spatial discrimination: Bertrand vs. Cournot in a model of location choice", Regional Science and Urban Economics, Vol. 19, No.1, pp. 87-102, doi: 10.1016/0166-0462(89)90035-5.

Hamoudi. H., Risueño, M. (2012) "The Effects of Zoning in Spatial Competition", Journal of Regional Science, Vol. 52, No. 2, pp. 361-374, doi: 10.1111/j.14679787.2011.00744.x.

Hotelling, H. (1929) "Stability in competition", Economic Journal, Vol. 39, No. 153, pp. 41-57, doi: 10.2307/2224214.

Hoover, E. M. (1937) "Spatial Price Discrimination", Review of Economic Studies, Vol. 4, No. 3, pp. 182-191, doi: 10.2307/2967453.

Hurter, A. (1985) "Spatial Duopoly with Discriminatory Pricing", Regional Science and Urban Economics, Vol. 15, No. 4, pp. 541-553, doi: 10.1016/01660462(85)90040-7.

Lai, F., Tsai, J. (2004) "Duopoly location and optimal zoning in a small open city", Journal of Urban Economics, Vol. 55, No. 3, pp. 614-626, doi: 10.1016/j. jue.2003.12.003.

Lederer, P., Hurter, A. (1986) "Competition of Firms: Discriminatory Pricing and Location”, Econometrica, Vol. 54, No. 3, pp. 623-640, doi: 10.2307/1911311.

Lerner, A. P., Singer, H. W. (1937) "Some notes on duopoly and spatial competition," Journal of Political Economy, Vol. 45, No. 2, pp. 145-186, doi: 10.1086/255039.

Matsumura, T., Shimizu, D. (2005) "Economic welfare in delivered pricing duopoly: Bertrand and Cournot", Economics Letters, Vol. 89, No. 1, pp. 112-119, doi: 10.1016/j.econlet.2005.05.019.

World Health Organization (2016) Urban green spaces and health. Copenhagen: WHO Regional Office for Europe. 


\title{
Uredba zelenog prostornog uređenja pod diskriminacijom cijena ${ }^{1}$
}

\author{
Hamid Hamoudi ${ }^{2}$, María J. Moral ${ }^{3}$
}

\begin{abstract}
Sažetak
Ova studija ima za cilj ispitati urbano prostorno uređenje unutar linearnog grada u okviru Bertrandovog duopolskog natjecanja s diskriminacijom cijena i linearnim transportnim troškovima linearnog prijevoza. Analiziraju se učinci uvođenja područja zaštite okoliša u kojima gospodarska i stambena aktivnost nisu dopuštene. Funkcija blagostanja koja se koristi za određivanje optimalne veličine zelenog područja omogućava eventualnu pristranost regulatora u korist tvrtki/ potrošača. Konkurencija za lokacijsku cijenu može utjecati na smanjenje ili povećanje cijene ovisno o veličini zelene površine. Rezultati ukazuju na to da regulator koji provodi zeleno zoniranje, pod linearnim troškovima prijevoza, utječe na optimalno mjesto poduzeća (jer ta mjesta ovise o veličini zelene zone). Kao posljedica toga, zoniranje se može koristiti kao učinkovit alat industrijske ili urbane politike.
\end{abstract}

Ključne riječi: prostorna diskriminacija, duopol, zoniranje, utjecaji na okoliš

JEL klasifikacija: D43, L13, R38, Q58

1 Druga autorica zahvaljuje na financijskoj potpori ovom projektu od strane Španjolskog Ministarstva znanosti i inovacija, odobrenoj pod brojem ECO2014-52051R i ECO201569334

2 Izvanredni profesor, Department of Foundations of Economic Analysis, Faculty of Legal and Social Sciences, University of King Juan Carlos (URJC), Paseo de los Artilleros s/n, 28032. Madrid, Śpanjolska. Znanstveni interes: mikroekonomija i industrijska organizacija. Tel.:+349 1488 7853. E-mail: hamid.hamoudi@urjc.es. Osobnaweb stranica: https://gestion2.urjc.es/ curriculum/ pdicv?id= hamid.hamoudi.

3 Izvanredna profesorica, Department of Applied Economics, National Distance Education University (UNED), Paseo Senda del Rey s/n, 28040, Madrid, Španjolska. Znanstveni interes: mikroekonomija i industrijska organizacija.Tel.: +34913988930.E-mail: mjmoral@cee.uned. es. Osobna web stranica: http://mjmoral.webs.uvigo.es/(osoba za kontakt). 


\section{Appendix}



Proof of proposition 1:

Let the welfare function be expressed as:

$W_{1}(v)=N\left\{\left[\frac{1}{8} t(9 \lambda-4)\right] v+(1-\lambda)\left[S-c-\frac{t}{2}\right]+\frac{3}{8} \lambda t\right\}$

The derivative of $W_{1}(v)$ is given by: $\partial W_{1}(v) / \partial v=(1 / 8) t(9 \lambda-4)$. Therefore, it is shown that: $\partial W_{1}(v) / \partial v \leq 0$, is $\lambda \in[0,0.44]$ and $\partial W_{1}(v) / \partial v \geq 0$, if $\lambda \in[0.44,1]$.

Consequently, the following solutions are obtained:

$\operatorname{Arg} \underset{0 \leq v \leq \hat{v}}{\operatorname{Max}} W_{1}(v)=v^{O M}=\left\{\begin{array}{lll}0 & \text { if } & 0 \leq \lambda \leq 0.44 \\ {[0, \hat{v}]} & \text { if } & \lambda=0.44 \\ \hat{v} & \text { if } & 0.44 \leq \lambda \leq 1\end{array}\right.$.

Proof of proposition 2:

Let $W_{2}(v)$ be a welfare function given by: $W_{2}(v)=N(1-\lambda)\left\{-v_{2}+[\gamma+t f(\lambda)] v+K\right\}$, where $f(\lambda)$ and $K$ are defined in the main text.

The following is solved for $\frac{\partial W_{2}(v)}{\partial v}=0$ and the next result is obtained: $v^{*}=\frac{1}{2}(\gamma+t f(\lambda))$. It can then be verified when $v^{*} \in[0, \hat{v}]$ and when not:

\begin{tabular}{ccc}
\hline$v^{*} \leq 0$ & $\leftrightarrow$ & $\gamma \leq-t f(\lambda)$ \\
\hline $0 \leq v^{*} \leq \hat{v}$ & $\leftrightarrow$ & $-t f(\lambda) \leq \gamma \leq 2-t f(\lambda)$ \\
\hline$v^{*} \geq \hat{v}$ & $\leftrightarrow$ & $2-t f(\lambda) \leq \gamma$ \\
\hline
\end{tabular}

Then:

For $\gamma \leq-t f(\lambda)$ then $v^{*} \leq 0$, after $v_{3}^{o}=\operatorname{Arg} \underset{0 \leq v \leq \hat{v}}{\operatorname{Max}} W_{3}(v)=0$

For $-t f(\lambda) \leq \gamma \leq 2-t f(\lambda)$, it is obtained that $0 \leq v^{*} \leq \hat{v}$ and the solution corresponds to $v^{O G}=\operatorname{Arg} \underset{0 \leq v \leq \hat{v}}{\operatorname{Max}} W_{2}(v)=v^{*}$.

For $2-t f(\lambda) \leq \gamma$, which implies $v^{*} \geq \hat{v}$. In this case it is shown that:

$v^{O G}=\operatorname{Arg} \underset{0 \leq v \leq \hat{v}}{\operatorname{Max}} W_{2}(v)=\hat{v}$ 